\title{
THE EFFICIENCY OF LANDFILL LEACHATE TREATMENT USING THE FENTON'S REAGENT
}

\author{
Justyna Koc-Jurczyk'1, Lukasz Jurczyk ${ }^{1}$ \\ 1 Department of Biological Basis of Agriculture and Environmental Education, Faculty of Biology and Agriculture, \\ University of Rzeszow, Ćwiklińskiej 1, 35-601 Rzeszów, Poland, e-mail: jjurczyk@ur.edu.pl; ljurczyk@ur.edu.pl
}

Received: 2015.05.15

Accepted: 2015.06.02

Published: 2015.07.01

\begin{abstract}
In this studies the influence of the dose and ratio of chemical reagents $\left(\mathrm{Fe}^{2+}\right.$ and $\left.\mathrm{H}_{2} \mathrm{O}_{2}\right)$ on the efficiency of COD removal and changes of $\mathrm{BOD}_{5} / \mathrm{COD}$ ratio in landfill leachate was analysed. The molar $\mathrm{Fe}^{2+} / \mathrm{H}_{2} \mathrm{O}_{2}$ ratio was lower than 1 and amounted to: 1:10, 1:5, $1: 3$, three research series with $1 ; 2.5$ and $5 \mathrm{~g} / \mathrm{L} \mathrm{Fe}^{2+}$ concentration. A higher efficiency in removing $\mathrm{BOD}$ than $\mathrm{COD}$, and therefore the decrease of $\mathrm{BOD}_{5} / \mathrm{COD}$ ratio in effluent was stated. The efficiency of COD removal from leachate was from $58.34 \%$ $\left(\mathrm{Fe}^{2+} 0.5 \mathrm{~g} / \mathrm{L}, \mathrm{Fe}^{2+} / \mathrm{H}_{2} \mathrm{O}_{2} 1: 5\right)$ to $8.33 \%\left(\mathrm{Fe}^{2+}=0.1 \mathrm{~g} / \mathrm{L}, \mathrm{Fe}^{2+} / \mathrm{H}_{2} \mathrm{O}_{2}=1: 10\right)$, while the efficiency of BOD removal ranged from 62 to $77 \%$. With the molar ratio $\mathrm{Fe}^{2+} / \mathrm{H}_{2} \mathrm{O}_{2}$ equal 1:5 the $\mathrm{BOD}_{5} / \mathrm{COD}$ ratio was the largest for each of the analysed $\mathrm{Fe}^{2+}$ doses. The lowest $\mathrm{BOD}_{5} / \mathrm{COD}$ ratio was observed for the $\mathrm{Fe}^{2+}$ dose $0.1 \mathrm{~g} / \mathrm{L}$ and molar ratio of reagents $1: 3$.
\end{abstract}

Keywords: wastewater treatment, landfill leachate, Fenton's reagent.

\section{INTRODUCTION}

Landfilling is the most common method of municipal waste management, due to both technological and economic reasons. One of the drawbacks of this method of dealing with waste is the formation of leachate. Leachate result from the physical and chemical as well as biological changes, occurring in the bed and rainwater percolating through layers of waste [Hermosilla et al. 2009].

Characteristics of leachate depend on the composition and amount of deposited waste, construction and operational conditions of landfill, and most of all on the age of the landfill. Leachate from young landfills, being in the acidic phase, are characterised by low $\mathrm{pH}$, average concentrations of ammonium nitrogen $(500-2000 \mathrm{mg} / \mathrm{L})$, high concentrations of organic substances expressed as BOD (4000 - $13000 \mathrm{mg} / \mathrm{L})$ and COD (30 $000-$ $60000 \mathrm{mg} / \mathrm{L}$ ) so as a result the value of BOD/ COD coefficient is high and ranges from 0.4 to 0.7. During the methanogenic phase in leachate appear non-biodegradable organic substances, the degradation of volatile fatty acid (VFA) occurs, and $\mathrm{pH}$ increases to approximately 7 . Along with the time of landfilling and increased advantage of anaerobic processes taking place in the bed, ammonium nitrogen appears in leachate in high concentrations $(3000-5000 \mathrm{mg} / \mathrm{L})$, the value of COD is $5000-20,000 \mathrm{mg} / \mathrm{L}$, and $\mathrm{BOD} / \mathrm{COD}$ ratio is lower than 0.1 [Foo, Hameed, 2009, Guo et al. 2010, Ahmed, Lan 2012].

Leachate treatment with biological methods is widely used, most of all due to low operating costs. However, these methods do not provide sufficient efficiency of the removal of organic substances resistant to biological degradation, whose amount increases in later phases of biochemical changes of the landfill. Therefore, for treatment leachate from old landfills, more expensive physicochemical processes, such as: coagulation and flocculation [Amokrane et al. 1997, Aziz et al. 2007], adsorption on activated carbon [Foo, Hameed 2009], membrane filtration [Tabet et al. 2002, Li et al. 2010] or advanced oxidation [Rivas et al. 2004, Singh, Tank 2013] are used. 
Although the process of advanced oxidation using Fenton's reagent was discovered and described over 100 years ago, this method was adapted to remove refractory substances from leachate only in the 90s (Huang et al., 1993). In this process there is used $\mathrm{H}_{2} \mathrm{O}_{2}$ as oxidiser and $\mathrm{Fe}^{2+}$ as a catalyst, in order to create hydroxyl radicals $\left(\mathrm{OH}^{\circ}\right)$ (equations $1-5$ ) [Singh, Tang 2013].

$$
\begin{gathered}
\mathrm{Fe}^{2+}+\mathrm{H}_{2} \mathrm{O}_{2} \rightarrow \mathrm{Fe}^{3+}+\mathrm{OH}^{-}+\mathrm{OH}^{\cdot} \\
\mathrm{Fe}^{3+}+\mathrm{H}_{2} \mathrm{O}_{2} \rightarrow \mathrm{HO}_{2}^{-}+\mathrm{H}^{+} \\
\mathrm{RH}+\mathrm{OH}^{\cdot} \rightarrow \mathrm{H}_{2} \mathrm{O}+\mathrm{R}^{\cdot} \\
\mathrm{OH}^{-}+\mathrm{H}_{2} \mathrm{O}_{2} \rightarrow \mathrm{HO}_{2}^{\cdot}+\mathrm{H}_{2} \mathrm{O} \\
\mathrm{Fe}^{2+}+\mathrm{OH}^{\cdot} \rightarrow \mathrm{Fe}^{3+}+\mathrm{OH}^{-}
\end{gathered}
$$

Hydroxyl radicals efficiently mineralise or convert indecomposable organic compounds to biodegradable forms, which are then removed in biological processes. During reactions between substances dissolved in landfill leachate and Fenton's reagent, compounds with high molecular mass are converted into compounds with low mass, and complex aromatic and aliphatic hydrophobic chains are transformed to substances with the hydrophilic structure [Zhao et al. 2013, KocJurczyk 2014]. The effectiveness of the process depends on the $\mathrm{pH}$, doses and molar ratio of reactants $\left(\mathrm{Fe}^{2+}\right.$ and $\left.\mathrm{H}_{2} \mathrm{O}_{2}\right)$ and ratios $\mathrm{H}_{2} \mathrm{O}_{2} / \mathrm{COD}$ as well as $\mathrm{Fe}^{2+} / \mathrm{COD}$.

The aim of the study was the assessment of effectiveness of organic substances removal with the method of advanced oxidation with Fenton's reagent. In the study the influence of varied doses of Fenton's reagent $\left(\mathrm{Fe}^{2+}\right.$ and $\left.\mathrm{H}_{2} \mathrm{O}_{2}\right)$ and molar ratio of reagents to such parameters like effectiveness of removing organic substances expressed as $\mathrm{COD}$ and $\mathrm{BOD}_{5}$, as well as the change of the relation $\mathrm{BOD}_{5} / \mathrm{COD}$ were determined.

\section{METHODOLOGY}

\section{Materials}

For research raw leachate derived from 22 year old municipal landfill in Kozodrza (Poland) were used, which is the main landfill in the SubCarpathian region, where non-hazardous municipal wastes are received in the average amount of 55.8 thousand $\mathrm{Mg} / \mathrm{y}$. Leachates were characterised by the concentration of organic substances expressed as COD on the level of $4785 \mathrm{mg} / \mathrm{L}$, and $\mathrm{BOD}_{5}-636 \mathrm{mg} / \mathrm{L}$. Accordingly, the ratio of $\mathrm{BOD}_{5} / \mathrm{COD}$ was 0.13 . Mixed leachates were col- lected from the retention reservoir to $25 \mathrm{~L}$ plastic tanks and immediately transported to the laboratory, where they were stored for further analyses in $4{ }^{\circ} \mathrm{C}$ in the dark.

\section{Experimental procedure}

Studies on the leachate treatment with the Fenton's reagent were conducted in static conditions, in laboratory reactors with the capacity of 1 $\mathrm{L}$, at a temperature $20^{\circ} \mathrm{C}$ using $100 \mathrm{rpm}$ stirring. Chemical reagents were dosed once at the beginning of the cycle, in the mixing phase, directly to the reactor. As the first one, $\mathrm{FeSO}_{4} \times 7 \mathrm{H}_{2} \mathrm{O}$ was injected to the reactor, and directly after $\mathrm{H}_{2} \mathrm{O}_{2}$ (30\%). Due to the application character of studies in the course of the experiment, the $\mathrm{pH}$ was not adjusted. The $\mathrm{pH}$ raw leachate was 8.57.

Three research series with different concentration $\mathrm{Fe}^{2+}(1 ; 2.5$ and $5 \mathrm{~g} / \mathrm{L})$ were conducted. While for each $\mathrm{Fe}^{2+}$ concentration increasing doses of $\mathrm{H}_{2} \mathrm{O}_{2}$, were added obtaining as a result molar ratios of $\mathrm{Fe}^{2+} / \mathrm{H}_{2} \mathrm{O}_{2}$ lower than 1, equal: 1:10, 1:5, 1:3. The proportions, $\mathrm{H}_{2} \mathrm{O}_{2} / \mathrm{COD}$ in raw leachate was from 0.125 to 1.8 (Figure 1), while the proportion $\mathrm{Fe}^{2+} / \mathrm{COD}$ ranged from 0.02 to 0.1 (Figure 2).

In order to determine the effectiveness of the leachate treatment process by Fenton's reagent,

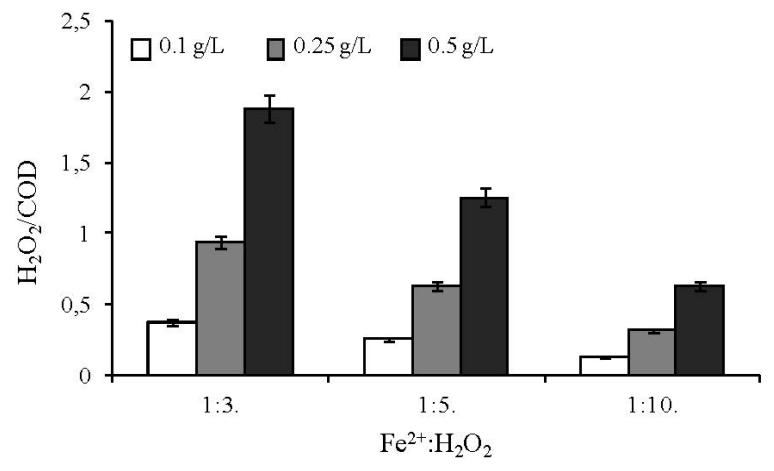

Figure 1. Doses of hydrogen peroxide expressed as a ratio to $\mathrm{COD}$ concentration in raw leachate

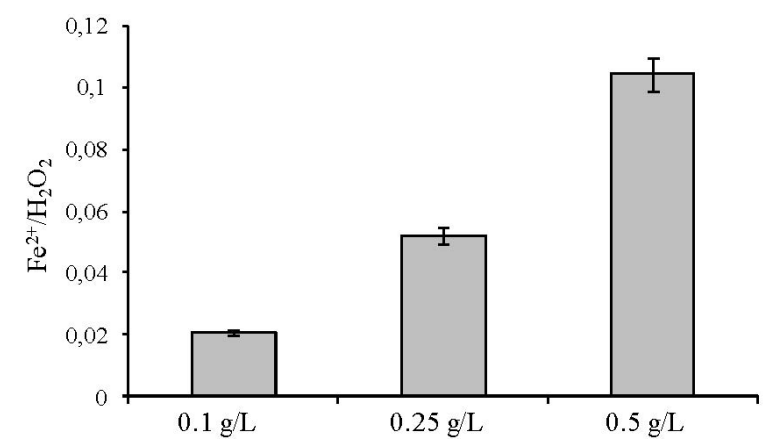

Figure 2. Doses of iron(II) sulfate expressed as a ratio to COD concentration in raw leachate 
the concentrations of organic substances as COD were analysed, according to the standard PN-ISO 6060:2006P, concentration of organic substance as $\mathrm{BOD}_{5}$ (DIN EN1899-1/EN 1899-2) and $\mathrm{pH}$ value (Elmetron CPC-401). Samples for organic matter measurement were collected after $1 \mathrm{~h}$ of mixing and $0.5 \mathrm{~h}$ of sedimentation after addition of reagents.

\section{RESULTS AND DISCUSSION}

In raw leachate concentration of organic substances expressed as $\mathrm{COD}$ and $\mathrm{BOD}_{5}$ was respectively $4785 \mathrm{mg} / \mathrm{L}$ and $636 \mathrm{mg} / \mathrm{L}$. After the treatment with the method of advanced oxidation using Fenton's reagent, regardless of the dose and ratio of the used reagents, both $\mathrm{COD}$, and $\mathrm{BOD}_{5}$ was lowered (Figure 3).

It was stated that regardless of the molar $\mathrm{Fe}^{2+} / \mathrm{H}_{2} \mathrm{O}_{2}$ ratio, the lowest concentration of organic substances expressed as COD in the treated leachate was observed in the $\mathrm{Fe}^{2+}$ dose equal 0.5 $\mathrm{g} / \mathrm{L}$. For the ratio of reagents $1: 3,1: 5$ and $1: 10$ this value was, respectively, 2051, 1993 and 3930 $\mathrm{mg} / \mathrm{L}$. The smallest effectiveness of removing organic substances was stated for the dose $\mathrm{Fe}^{2+} 0.1$ g/L (respectively; 3191, 2734 and $4386 \mathrm{mg} / \mathrm{L}$ ).

Numerous literature data report the increase of concentration of biodegradable organic matter expressed as $\mathrm{BOD}_{5}$ after the application of the advanced oxidation for the treatment of wastewater [Renou et al. 2008, Umar et al. 2010]. In this study, a decrease of $\mathrm{BOD}_{5}$ concentration in each of the proposed technological variants was observed. In case of using $\mathrm{Fe}^{2+} / \mathrm{H}_{2} \mathrm{O}_{2}$ 1:10 ratio, the $\mathrm{BOD}_{5}$ concentration in the outflow was 240 $\mathrm{mg} / \mathrm{L}$, regardless of the used $\mathrm{Fe}^{2+}$ dose. The lowest concentration of biodegradable forms of organic carbon was obtained after using the molar ratio of reagents $1: 3$ and $\mathrm{Fe}^{2+}$ doses 0.1 or $0.5 \mathrm{~g} / \mathrm{L}$ (respectively 145 and $150 \mathrm{mg} / \mathrm{L}$ ).

The efficiency of removing organic compounds expressed as COD from leachate was highest with the molar ratio of reagents $1: 3$ and $1: 5$ and for the dose $\mathrm{Fe}^{2+} 0.5 \mathrm{~g} / \mathrm{L}$, and was respectively 57.13 and $58.34 \%$. The lowest removal efficiency of organic compounds expressed as COD occurred for the ratio of $1: 10$, and for doses $\mathrm{Fe}^{2+} 0.1,0.25$ and $0.5 \mathrm{~g} / \mathrm{L}$ and equals respectively $8.33 ; 13.1$ and $17.8 \%$. With the increase of the $\mathrm{Fe}^{2+}$ dose, the efficiency of removing organic carbon (COD) grows, regardless on the molar ratio of reagents.

Considering the concentration of biodegradable organic substances $\left(\mathrm{BOD}_{5}\right)$ its decrease was also observed and so the efficiency of removing $\mathrm{BOD}_{5}$ was also calculated. The efficiency of treatment was higher than in case of COD (Figure 4) and was within the range from 62 to $77 \%$. The highest efficiency of $\mathrm{BOD}_{5}$ removal was stated in case of using the 1:3 molar ratio of reagents, regardless of the dose $\mathrm{Fe}^{2+}$.

Highly reactive forms of oxygen formed during Fenton's reaction lead to the simplification of the structure of complex organic compounds so the authors observe the decrease of COD, at the expense of simultaneous increase of $\mathrm{BOD}_{5}$. Zhao et al. [2013] and Singh, Tang [2013] report that macromolecular organic substances can be effec-

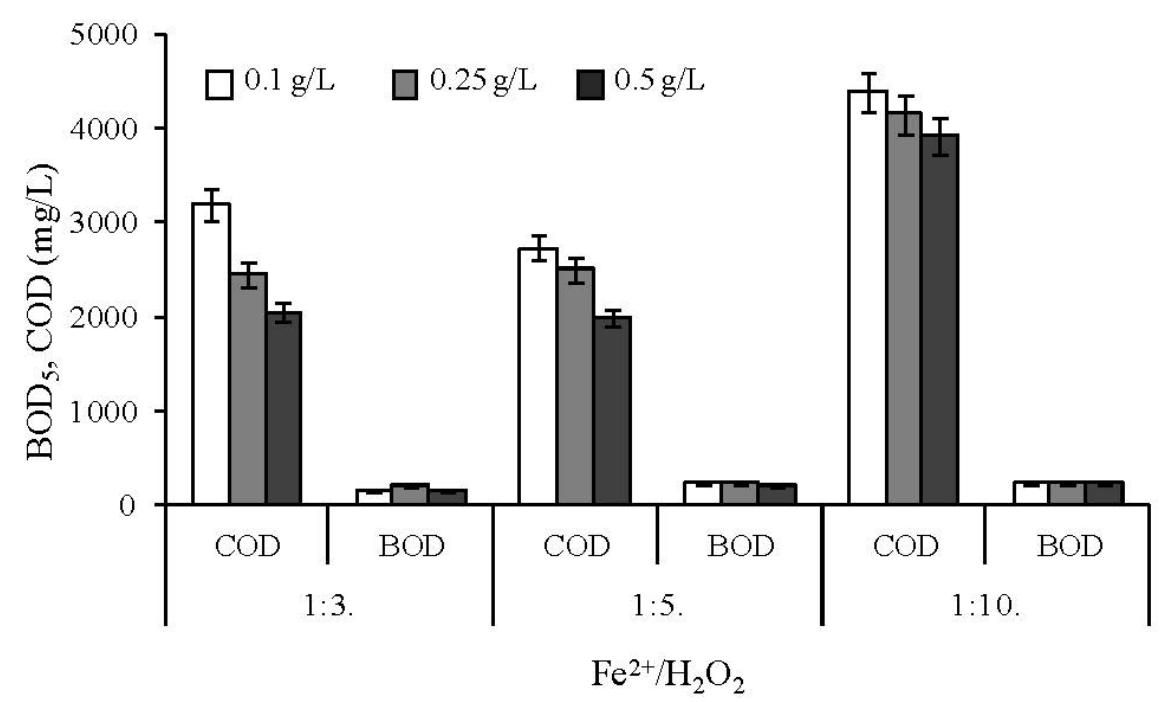

Figure 3. Concentration of organic compounds, expressed as COD and BOD, in leachates after Fenton's reagent treatment in different proportions 


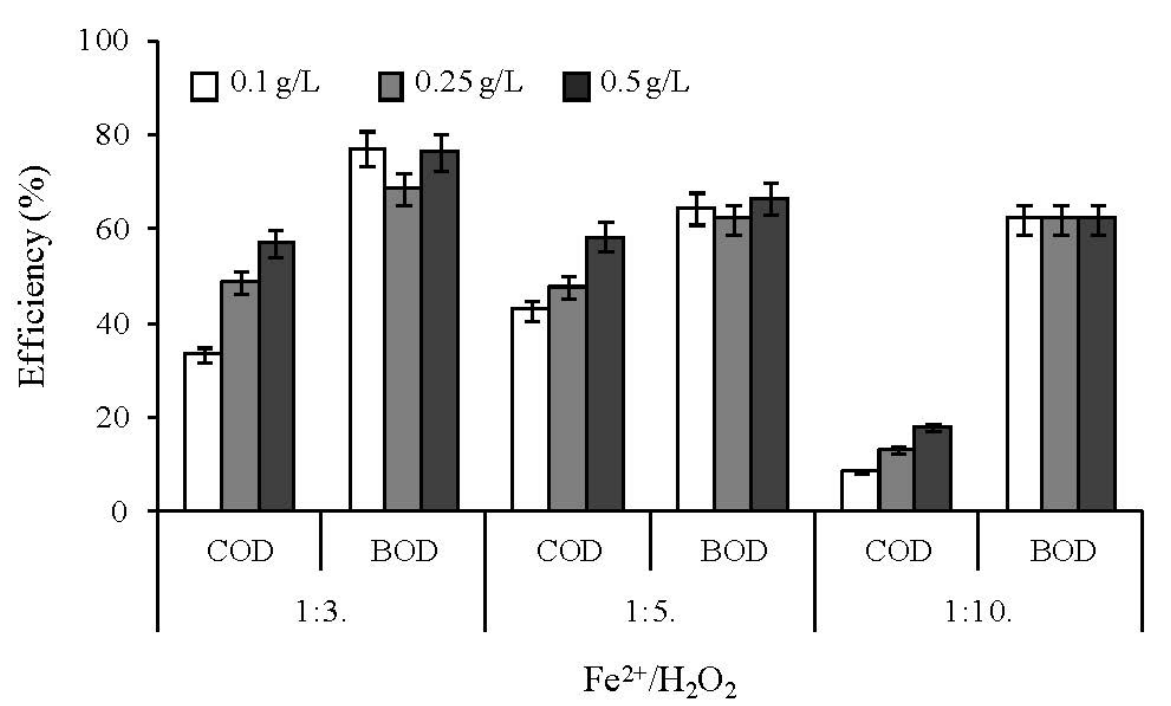

Figure 4. COD and BOD removal efficiency during the leachate treatment using Fenton's oxidation

tively oxidised using Fenton's reagent. While in this paper there was stated rather modest reduction of the COD value, with significant decrease of $\mathrm{BOD}_{5}$ and lowering $\mathrm{pH}$ value to the approximately 6. Probably, under conditions which were proposed in this experiment, much more biodegradable organic compounds underwent fully mineralisation to carbon dioxide, than non-biodegradable forms transformed into biodegradable.

Zhao et al. [2013] report that efficiency of removing COD during landfill leachate AOP treatment increased with the increase of the proportion $\mathrm{Fe}^{2+} / \mathrm{H}_{2} \mathrm{O}_{2}$ and achieved the highest value 86 and $73.4 \%$ respectively, with the $\mathrm{Fe}^{2+}$ dose 2.24 and $0.56 \mathrm{~g} / \mathrm{L}$. The increase of the proportion of reagents to 1:10 caused the decrease of efficiency of treatment, regardless of the iron dose.

According to Singh, Tang [2013] the optimal $\mathrm{Fe}^{2+}: \mathrm{H}_{2} \mathrm{O}_{2}$ molar ratio ranges from $2: 5$ to $1: 100$ (average 1:3) and effectiveness of leachate treatment ranges from 31 to $95 \%$. In case of treatment of raw leachate the proportion $\mathrm{Fe}^{2+} / \mathrm{H}_{2} \mathrm{O}_{2}$ ranges from 2:5 to 1:60 (effectiveness of the treatment $31-86 \%)$.

Effectiveness of treating leachate in Fenton's process depends on the concentration of both applied reagents. Although, as it is stated by Sing, Tang [2013] $\mathrm{H}_{2} \mathrm{O}_{2}$ is the main oxidiser to refraction substances.

The theoretical $\mathrm{H}_{2} \mathrm{O}_{2} / \mathrm{COD}$ ratio with chemical oxidation with Fenton's reagent is approx. 2.1. High efficiency of removing COD from leachate was obtained after the application of the $\mathrm{H}_{2} \mathrm{O}_{2}$ / COD proportion equal 3.3 [Primo et al. 2008]. In studies the proportion $\mathrm{H}_{2} \mathrm{O}_{2} / \mathrm{COD}$ was from 0.125 to 1.8 (Figure 1). Effectiveness of removing the chemical oxygen demand grew with the increase of proportion $\mathrm{H}_{2} \mathrm{O}_{2} / \mathrm{COD}$; with the proportion of 0.125 it was the lowest and reached $8.33 \%$, but after increasing the amount of $\mathrm{Fe}^{2+}$, and thus the increase of concentration of $\mathrm{H}_{2} \mathrm{O}_{2}$, the proportion $\mathrm{H}_{2} \mathrm{O}_{2} / \mathrm{COD}$ increased to 1.8 and 1.2 and the effectiveness of COD removing was the highest and was respectively 57 and $58.3 \%$. It was also stated that with the same proportion of $\mathrm{H}_{2} \mathrm{O}_{2} / \mathrm{COD}$ equal 0.62 , the effectiveness of removing COD was different, depending on the dose and molar ratio of reagents. With the dose $\mathrm{Fe}^{2+} 0.25 \mathrm{~g} / \mathrm{L}$ and ratio $\mathrm{Fe}^{2+} / \mathrm{H}_{2} \mathrm{O}_{2}$ 1:5 effectiveness of removing COD was $47.6 \%$. After increasing the dose of $\mathrm{Fe}$ to 0.5 $\mathrm{g} / \mathrm{L}$ and increasing the share of $\mathrm{H}_{2} \mathrm{O}_{2}$ in the reacting mixture $\left(\mathrm{Fe}^{2+} / \mathrm{H}_{2} \mathrm{O}_{2}=1: 10\right)$ effectiveness decreased to $17.8 \%$. As it is reported by scientific papers, the optimal $\mathrm{H}_{2} \mathrm{O}_{2} / \mathrm{COD}$ ratio for raw leachate treating is higher in comparison to optimal dose for preliminary-treated leachate. For the $\mathrm{H}_{2} \mathrm{O}_{2} / \mathrm{COD}$ ratio lower than 10 , effectiveness of COD removal is between $31-95 \%$. Increasing the dose of $\mathrm{H}_{2} \mathrm{O}_{2}$ does not influence the increase of effectiveness of cleaning. The greatest effectiveness of treatment ( 31 to $85 \%$ ) was obtained using the ratio $\mathrm{H}_{2} \mathrm{O}_{2} / \mathrm{COD}$ of $0.7-1.2$. [Singh, Tang 2013]. Hermosilla et al. [2009] used the ratio $\mathrm{H}_{2} \mathrm{O}_{2} / \mathrm{COD}$ of 0.42 and obtained $80 \%$ of efficiency for treating raw leachate derived from young landfill. However, the same technological conditions in case of leachate from average and old landfills resulted in the lowering of effectiveness to less than $70 \%$.

As it follows from the above mentioned data, the ratio of $\mathrm{H}_{2} \mathrm{O}_{2} / C O D$ used in the studies was correct, and the lower effectiveness of treatment 
than the one given in literature may result from the lack of regulation of the $\mathrm{pH}$. Due to the application character of this study, the $\mathrm{pH}$ equilibration step was abandoned, because of technological problems and additional costs that may occur in technical scale on the treatment plant.

The initial oxidation of organic compounds depends also on the concentration of $\mathrm{Fe}^{2+}$. In this studies the ratio of $\mathrm{Fe}^{2+} / \mathrm{COD}$ in the range from 0.02 to 0.1 was used (Figure 2). An increase of effectiveness of COD removal with the increase of $\mathrm{Fe}^{2+} / \mathrm{COD}$ was observed regardless of the $\mathrm{Fe}^{2+} / \mathrm{H}_{2} \mathrm{O}_{2}$ ratio. The influence of the amount of $\mathrm{H}_{2} \mathrm{O}_{2}$ on leachate treatment efficiency was also observed - in low concentrations of $\mathrm{H}_{2} \mathrm{O}_{2}\left(\mathrm{Fe}^{2+} /\right.$ $\mathrm{H}_{2} \mathrm{O}_{2}=1: 3$ ) effectiveness of treatment was 33 to $57 \%$ but after increasing $\mathrm{Fe}^{2+} / \mathrm{H}_{2} \mathrm{O}_{2}$ ratio to $1: 10$ the effectiveness lowered significantly to values from 8.33 to $17.8 \%$. As it is reported by Sing, Tang [2013] with the increase of $\mathrm{Fe}^{2+}$ amount in reagent mix, the rate of organic compound oxidation grows. However, if the amount of $\mathrm{Fe}^{2+}$ will be exceeded, the iron ions (II) compete with organic substances for $\mathrm{OH}^{\cdot}$ radicals. In this case the process of coagulation starts to dominate, producing the additional chemical sludge [Neyens, Baeyens 2003]. Sing, Tang [2013] report that the optimal $\mathrm{Fe}^{2+} / \mathrm{COD}$ ratio ranges between 0.01 and 14.9 (on average 0.8). Just like in case of $\mathrm{H}_{2} \mathrm{O}_{2} / \mathrm{COD}$ ratio, increasing the $\mathrm{Fe}^{2+} / \mathrm{COD}$ proportions does not result in the increase of the effectiveness of treatment.

When $\mathrm{Fe}^{2+}$ or $\mathrm{H}_{2} \mathrm{O}_{2}$ are in the excess, they are consuming $\mathrm{OH}^{\cdot}$ radicals, what inhibits COD removal (Eq. 6 and 7) [Sign, Tang 2013, Zhao et al. 2013].

$$
\begin{gathered}
\mathrm{H}_{2} \mathrm{O}_{2}+\mathrm{OH}^{\cdot} \rightarrow \mathrm{HO}_{2}^{\cdot}+\mathrm{H}_{2} \mathrm{O} \\
\mathrm{Fe}^{3+}+\mathrm{HO}_{2}^{\cdot} \rightarrow \mathrm{Fe}^{2+}+\mathrm{O}_{2}+\mathrm{H}^{+}
\end{gathered}
$$

The excess of $\mathrm{H}_{2} \mathrm{O}_{2}$ may also cause flotation of the sludge due to the presence of $\mathrm{O}_{2}$ in the gaseous form [Singh, Tang 2013].

As a measure of the biodegradability potential of organic compounds in leachate, the ratio of organic carbon measured as BOD to organic carbon measured as COD is widely accepted. Thus, this ratio is the uppermost indicator from the technological point of view, when designing biological treatment of leachate is planned for a given object. In this case, raw leachate was characterised with the ratio $\mathrm{BOD}_{5} / \mathrm{COD}$ at the level of 0.13 .

Due to a slight reduction of COD concentration and quite large $\mathrm{BOD}_{5}$ decrease, the ratio between both indicators after treatment became lower than before, regardless of the applied research variant (Figure 5).

The lowest $\mathrm{BOD}_{5} / \mathrm{COD}$ ratio was observed for the dose of $\mathrm{Fe}^{2+} 0.1 \mathrm{~g} / \mathrm{L}$ with the molar ratio of reagents 1:3 (0.04). At the ratio 1:10 the obtained results were comparable and were 0.05 and 0.06 for doses of $\mathrm{Fe}^{2+}$ respectively 0.1, 0.25 and $0.5 \mathrm{~g} / \mathrm{L}$. When molar ratio $\mathrm{Fe}^{2+} / \mathrm{H}_{2} \mathrm{O}_{2}$ was $1: 5$ the $\mathrm{BOD}_{5} / \mathrm{COD}$ ratio was the highest for each of the analysed $\mathrm{Fe}^{2+}$ doses; in the concentration of $0.5 \mathrm{~g} / \mathrm{L}$ reaches 0.106 , and with higher $\mathrm{Fe}^{2+}$ concentrations, 0.1 and $0.25 \mathrm{~g} / \mathrm{L}$, this values were respectively 0.08 and 0.09 .

In the experiment there was used $1 \mathrm{~h}$ of reaction and $0.5 \mathrm{~h}$ sedimentation, which corresponds to the requirements of further technical scale application. However similar conditions of the process were used by Lopez et al. [2004], Mohajeri et al. [2011] and Singh, Tang [2013] in laboratory scale too. Zhang et al. [2006] report that the rapid degradation of macromolecular organic compounds occurs during first 30 minutes of mixing. In turn,

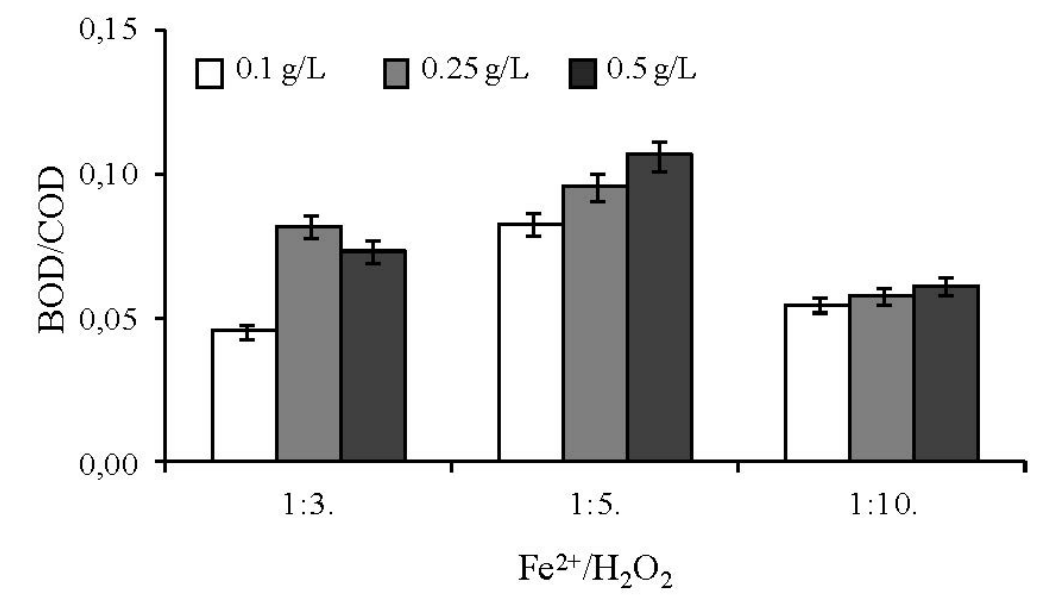

Figure 5. Changes of $\mathrm{BOD}_{5} / \mathrm{COD}$ ratio in leachate after Fenton's reagent treatment in different proportions 
Goi et al. [2010] report that the best effectiveness of removing macromolecular substances is provided only after 24 hour reaction. The increase of time of reaction does not always correspond to the higher effectiveness of COD removal. Gotvajn et al. [2009] obtained $86 \%$ of COD removing during the time of 10 minutes, and Kim, Huh [1997] 67\% effectiveness of COD removing in the time of 2 days.

\section{CONCLUSIONS}

The study analysed the influence of $\mathrm{Fe}^{2+}$ dose and molar ratio of $\mathrm{Fe}^{2+} / \mathrm{H}_{2} \mathrm{O}_{2}$ on the effectiveness of removing leachate organic compounds expressed as $\mathrm{COD}$ and $\mathrm{BOD}_{5}$ and the changes of $\mathrm{BOD}_{5} / \mathrm{COD}$ ratio from a landfill. It was stated that the effectiveness of removing organic substances (COD) ranged from 8.33 to $58.34 \%$. The most effective was the dose of $\mathrm{Fe}^{2+}$ equal $0.5 \mathrm{~g} / \mathrm{L}$ in ratio 1:5.

Also the influence of $\mathrm{H}_{2} \mathrm{O}_{2} / \mathrm{COD}$ was analysed ratio; the lowest effectiveness of treatment was obtained with the ratio equal 0.125 , the highest one with 1.2. It was observed that with such small ratio $\mathrm{H}_{2} \mathrm{O}_{2} / \mathrm{COD}(0.62)$ effectiveness of treatment of leachate depended on the concentration and molar ratio of reagents. With the increase of $\mathrm{Fe}^{2+}$ concentration from 0.25 to $0.5 \mathrm{~g} / \mathrm{L}$ and increase of proportion of $\mathrm{H}_{2} \mathrm{O}_{2}$ in the reacting mixture from 1:5 to $1: 10$ effectiveness of treatment decreased from 47.6 to $17.78 \%$. Analyzing the influence of the $\mathrm{Fe}^{2+} / \mathrm{COD}$ ratio on the effectiveness of treatment, there was stated the negative influence of the increase of $\mathrm{H}_{2} \mathrm{O}_{2}$ proportion in the reacting mixture.

In the studies higher effectiveness of $\mathrm{BOD}_{5}$ removal than $\mathrm{COD}$ was also stated, what caused the decrease of proportion $\mathrm{BOD}_{5} / \mathrm{COD}$ in leachate after treatment. Presumably, in proposed technological conditions the biodegradable organic compounds were more susceptible to convert to mineral forms, than refractory macromolecular compounds to biodegradable forms.

\section{REFERENCES}

1. Ahmed F.N., Lan C.Q. 2012. Treatment of landfill leachate using membrane bioreactors: A review. Desalination, 287, 41-54.

2. Amokrane A., Comel C., Veron J. 1997. Landfill leachates pretreatment by coagulation-flocculation. Water Res., 31, 2775-2782.
3. Aziz H.A., Alias S., Adlan M.N., Asaari F.A.H.,. Zahari M.S. 2007. Colour removal from landfill leachate by coagulation and flocculation processes. Bioresource Technol., 98, 218-220.

4. Foo K.Y., Hameed B.H. 2009. An overview of landfill leachate treatment via activated carbon adsorption process. J. Hazard. Mater., 171, 54-60.

5. Goi A., Trapido M. 2002. Hydrogen peroxide photolysis. Fenton reagent and photo-Fenton for the degradation of nitrophenols: a comparative study. Chemosphere, 46, 913-922.

6. Gotvajn A.Ž., Zagorc-Končan J., Cotman M. 2011. Fenton's oxidative treatment of municipal landfill leachate as an alternative to biological process. Desalination, 275, 269-275.

7. Guo J.S., Abbas A.A., Chen Y.P., Liu Z.P., Fang F., Chen P. 2010. Treatment of landfill leachate using a combined stripping, Fenton, SBR, and coagulation process. J. Hazard. Mater., 178, 699-705.

8. Hermosilla D., Cortijo M.,. Huang C.P 2009. Optimizing the treatment of landfill leachate by conventional Fenton and photo-Fenton processes. Sci. Total Environ., 407, 3473-3481.

9. Huang C.P., Dong C., Tang Z. 1993. Advance chemical oxidation: its present role and potential future in hazardous waste treatment. Waste Manage., 13, 361-377.

10. Kim Y-K., Huh I-R. 1997. Enhancing biological treatability of landfill leachate by chemical oxidation. Environmental Eng. Sci., 14, 73-79.

11. Koc-Jurczyk J. 2014. Removal of Refractory Pollutants from Landfill Leachate Using Two-Phase System. Water Environ. Res., 86, 74-80.

12. Li H.S., Zhou S.Q., Sun Y.B., Lv J.A. 2010. Application of response surface methodology to the advanced treatment of biologically stabilized landfill leachate using Fenton's reagent. Waste Manage., 30, 2122-2129.

13. Lopez A., Pagano M., Volpe A., Pinto A.C.D. 2004. Fenton's pre-treatment of mature landfill leachate. Chemosphere, 54, 1005-1010.

14. Mohajeri S., Aziz H.A., Zahed M.A., Mohajeri L., Bashir M.J.K., Aziz S.Q., Adlan M.N., Isa M.H. 2011. Multiple responses analysis and modeling of Fenton process for treatment of high strength landfill leachate. Water Sci. Technol., 64, 1652-1660.

15. Neyens E., Baeyens J. 2003. A review of classic Fenton's peroxidation as an advanced oxidation technique. J. Hazard. Mater., 98, 33-50.

16. Primo O., Rueda A., Rivero M.J., Ortiz I. 2008. An integrated process, Fenton eactionultrafiltration, for the treatment of landfill leachate: pilot plant operation and analysis. Ind. Eng. Chem. Res., 47, 946-952.

17. Renou S., Givaudan J.G., Poulain S.D., Moulin P. 2008. Landfill leachate treatment: review and op- 
portunity. J. Hazard. Mater., 150, 468-493.

18. Rivas F.J., Beltran F., Carvalho F., Acedo B., Gimeno O. 2004. Stabilized leachates: sequential coagulation-flocculation plus chemical oxidation process. J. Hazard. Mater., 116, 95-102.

19. Singh S.K., Tang W.Z. 2013. Statistical analysis of optimum Fenton oxidation conditions for landfill leachate treatment. Waste Manage., 33, 81-88.

20. Tabet K., Moulin P., Vilomet J.D., Amberto A., Charbit F. 2002. Purification of landfill leachate with membrane processes: preliminary studies for an industrial plant. Sep. Sci. Technol., 37, 1041-1063.
21. Umar M., Aziz H.A., Yusoff M.S. 2010. Trends in the use of Fenton, electro-Fenton and photoFenton for the treatment of landfill leachate. Waste Manage., 30, 2113-2121.

22. Zhang H., Zhang D., Zhou J. 2006. Removal of COD from landfill leachate by electro-Fenton method. J. Hazard. Mater., 135, 106-111.

23. Zhao X., Wei X., Xia P., Liu H., Qu J. 2013. Removal and transformation characterization of refractory components from biologically treated landfill leachate by $\mathrm{Fe}^{2+} / \mathrm{NaClO}$ and Fenton oxidation. Sep. Purif. Technol., 116, 107-113. 